\title{
Correspondence
}

\section{Patient consent to case-note perusal during approval visits}

\section{DeAR SIRS}

It is now standard practice during Royal College approval visits for the approval team to peruse patient case-notes in order to access the quality of trainees' case histories. This is in accordance with College policy and judging from the experience of the Central Approval Panel (Sims, 1990) case-note recording remains an area of concern. Professor Sims reported that of 49 schemes visited in 1988 mandatory requirements pertaining to "Standard of case-note recording and medical records" were requested in 18 cases. Case-note perusal therefore serves an important role in helping to raise teaching standards.

But what of the consent of the patient whose chart is being perused? In my experience, charts are selected by Approval team members at random, opened, read in part, then returned. At no time is the consent of the patient obtained.

Perhaps it might be better if after a chart is selected, the relevant patient is spoken to, verbal consent obtained and then the chart perused. Consent could be obtained by either the approval team members themselves or by the accompanying consultants of the hospital or service being assessed. I imagine most patients would readily give consent. They would also be impressed at the high value so placed by the College on patient confidentiality. Perhaps the Central Approvals Panel might take up this suggestion?

St Brendan's Hospital

AIDAN MCGENNIS

Rathdown Road, Dublin 7

\section{Reference}

Sims, A. C. P. (1990) Recurrent themes from approval visits, Section 3 of Handbook for Clinical Tutors, The Royal College of Psychiatrists.

\section{Reply}

DeAR SirS

Dr Aidan McGennis is correct in saying that perusing a sample of case-notes is a valuable part of the assessment that takes place on approval visits and therefore helps to raise educational standards. I will ensure that his letter is drawn to the attention of the Central Approval Panel.

A. C. P. Sims President

\section{Patients' attitudes towards their involuntary detention in hospital}

DEAR SIRS

Debate concerning involuntary detention and treatment in hospital has long been topical. Some believe that patients should not be given psychiatric care against their will under any circumstances, while others feel it is justified by the resulting benefits. In the USA and Canada the attitudes and ideas of the patients themselves have been researched. We carried out a study to examine what detained patients in this country know and feel about their status.

The study was carried out over two months in a district psychiatric hospital, using an interviewer administered questionnaire. All acute patients subject to Section 2 or 3 were approached seven to ten days after they became involuntary (n 24).

Only $33 \%$ patients had used their rights of appeal but $39 \%$ did not remember having their rights explained and $28 \%$ were unaware of their status (a much smaller proportion than found in Canada (Toews et al, 1984)). However, $45 \%$ of those who had not used their rights stated that they had accepted their doctor's opinion. Surprisingly, not all patients would have liked the opportunity for voluntary status and not all patients wished to have the implications of sectioning explained. Twenty-one per cent felt more favourably towards their psychiatrist following sectioning and $60 \%$ felt a doctor was the best qualified to section. Suggestions to improve sectioning included staff be more understanding; more rapid appeal procedures; more doctors be involved; police be unable to section; sectioning be banned. Fifty-seven per cent of responders could think of no way to improve the process. When asked what they most disliked about sectioning, few mentioned involuntary treatment, despite the fact that this ensued in $93 \%$ cases. Forty-one per cent of patients disliked being unable to leave the premises and $35 \%$ found the hospital atmosphere restrictive and punitive.

There was, in keeping with previous findings (Toews, 1986), a drift over the first week from opposition to a more neutral stance and in some a feeling in favour of the section. Seventy-one per cent saw it as part of their treatment and $54 \%$ expressed positive feelings towards sectioning in general. A significant number believed they might have come to physical harm $(66 \%)$ or have harmed others $(27 \%)$ had they not been sectioned and most felt that family or friends should be warned about this. Although anger 
remained the predominant feeling there was a move towards indifference and a change in some to relief and security.

Central Hospital

Warwick CV35 7EE

\section{References}

Toews, J., El-Guebaly, N., Leckie, A. \& Harper, D. (1984) Patients' attitudes at the time of their commitment. Canadian Journal of Psychiatry, 29, 590-595.

- (1986) Change with time in patients' reactions to commital. Canadian Journal of Psychiatry, 31, 413-415.

\section{Junior psychiatrists and ECT practice}

DEAR SIRS

I read with interest the article by Henderson $e t$ al, 'Administration of electroconvulsive therapy: training, practice and attitudes' (Psychiatric Bulletin, March 1993, 17, 154-155).

This paper addresses some important issues and is a welcome contribution to the important debate which is emerging about the administration of ECT and junior psychiatrists. It is reassuring that $93 \%$ of junior psychiatrists were "confident" about their ECT practice. However, despite being a deceptively simple procedure, ECT administration requires a high level of skill and knowledge. My own confidence has decreased over the past two years as my understanding of ECT has increased.

Clinical outcome in patients receiving ECT may be influenced by a diverse range of variables in cluding patient age and sex, electrode placement, stimulus frequency, duration and energy, wave form (sinusoidal or square) and whether bi- or unidirectional (Abrams, 1992). Most of these factors can now be manipulated by the clinician (usually the $\mathrm{SHO} /$ registrar) using a variety of commercially available machines. A thorough examination of ECT practice in relation to these factors is now long overdue.

It has been my personal experience over the past couple of years that the relationship between these variables and response to ECT are very poorly understood by junior psychiatrists, as well as by a considerable proportion of senior colleagues. Since junior psychiatrists are in the "front line" in relation to the administration of ECT, much greater emphasis on training and understanding of ECT is needed. Greater knowledge of the ECT process will enable ECT to be tailored to the needs of the individual patient. This will help to minimise side effects and foster optimal conditions for clinical efficacy.

High Royds Hospital

STEPHEN CURRaN

Menston, Ilkley

West Yorkshire LS29 6AQ

\section{Reference}

Abrams, R. (1992) Electroconvulsive Therapy, Second edition. Oxford: Oxford University Press.

\section{The museum at Wakefield}

\section{DeAr Sirs}

Dr Spencer (Psychiatric Bulletin, March 1993, 17, 177) draws attention to the museum at Wakefield. $A$ book which throws a very particular light on the history of mental hospitals in this country is that written by the curator of the museum, Mr A. L. Ashworth and the late Dr John Todd, ${ }^{*}$ The House: Wakefield Asylum, 1818. It is of special interest since the chapters are based on successive medical Directors from the opening of the Hospital in 1818 to the termination of the Directorship system of management in 1933. The book therefore describes the ideas and work of these luminaries, from William (later Sir William) Charles Ellis to Professor Joseph Shaw Bolton. The backdrop to these descriptions is the development and life of the hospital, with vignettes of staff, patients, treatments and entertainments.

The West Riding Pauper Lunatic Asylum, later called Stanley Royd Hospital, was the sixth asylum to open in Britain following the County Asylums Act of 1808. Samuel Tuke, of The Retreat at York, played the major role in the planning of the hospital and, in Practical Hints on the Construction and Economy of Pauper Lunatic Asylums. The House, provides vivid descriptions of the humane William Ellis and the influential Sir James Crichton-Brown (the 'orator of medicine') who invited such men as J. Clifford Allbutt and Hughlings Jackson to contribute, as well as instituting teaching for medical students from Leeds. Crichton-Browne produced and edited the famous West Riding Lunatic Asylum Medical Reports. Sir David Ferrier pioneered research into the localisation of cerebral function in mental illness. The reclusive Dr William Bevan-Lewis wrote an early British text on psychiatric disorder. Joseph Shaw Bolton became one of the earliest (if not the first) professor of psychiatry and continued the tradition of education about mental illness. Henry Maudsley gained his introduction to treatment of the mentally ill at Wakefield before going South to found

*The book is in limited circulation. It is obtainable on direct application to: The Administrative Department, Stanley Royd Hospital, Aberford Road, Wakefield, West Yorks WF1 4DQ. Cost: $£ 15$ (£16.50 inc. postage). 